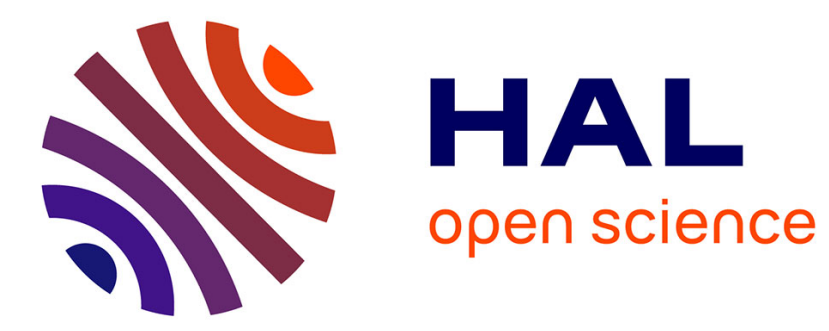

\title{
The contribution of agent-based simulations to conservation management on a Natura 2000 site
}

Hélène Dupont, Françoise Gourmelon, Mathias Rouan, Isabelle Le Viol, Christian Kerbiriou

\section{- To cite this version:}

Hélène Dupont, Françoise Gourmelon, Mathias Rouan, Isabelle Le Viol, Christian Kerbiriou. The contribution of agent-based simulations to conservation management on a Natura 2000 site. Journal of Environmental Management, 2016, 168, pp.27-35. 10.1016/j.jenvman.2015.11.056 . hal-01247332

\section{HAL Id: hal-01247332 \\ https://hal.science/hal-01247332}

Submitted on 5 Sep 2016

HAL is a multi-disciplinary open access archive for the deposit and dissemination of scientific research documents, whether they are published or not. The documents may come from teaching and research institutions in France or abroad, or from public or private research centers.
L'archive ouverte pluridisciplinaire $\mathbf{H A L}$, est destinée au dépôt et à la diffusion de documents scientifiques de niveau recherche, publiés ou non, émanant des établissements d'enseignement et de recherche français ou étrangers, des laboratoires publics ou privés. 
The contribution of agent-based simulations to conservation management on a Natura 2000 site.

Hélène Dupont ${ }^{1,2}$, Françoise Gourmelon ${ }^{1}$, Mathias Rouan ${ }^{1}$, Isabelle Le Viol ${ }^{2}$, Christian Kerbiriou $^{2}$

${ }^{1}$ LETG (UMR 6554 CNRS-Géomer), Institut Universitaire Européen de la Mer (OSU UMS 3113 CNRS), Université de Brest, UEB, rue Dumont d'Urville, 29280 Plouzané, France ${ }^{2}$ CESCO (UMR 7204 UPMC CNRS MNHN), Museum National d'Histoire Naturelle, 55 rue Buffon, 75005 Paris, France

Corresponding author: Christian Kerbiriou, kerbiriou@mnhn.fr, +33(0)140793831

\section{Summary}

The conservation of biodiversity today must include the participation and support of local stakeholders. Natura 2000 can be considered as a conservation system that, in its application in most EU countries, relies on the participation of local stakeholders. Our study proposes a scientific method for participatory modelling, with the aim of contributing to the conservation management of habitats and species at a Natura 2000 site (Crozon Peninsula, Bretagne, France) that is representative of in landuse changes in coastal areas. We make use of companion modelling and its associated tools (scenario-planning, GIS, multi-agent modelling and simulations) to consider possible futures through the co-construction of management scenarios and the understanding of their consequences on different indicators of biodiversity status (habitats, avifauna, flora). The maintenance of human activities as they have been carried out since the creation of the Natura 2000s zone allows the biodiversity values to remain stable. Extensive agricultural activities have been shown to be essential to this maintenance, whereas management sustained by the multiplication of conservation actions brings about variable results according to the indicators. None of the scenarios has a positive incidence on the set of indicators. However, an understanding of the modelling system and 
the results of the simulations allow for the refining of the selection of conservation actions in relation to the species to be preserved.

\section{Keywords}

companion modelling, Natura 2000, socio-ecological system, multi-agent model, participatory scenario-planning 


\section{Introduction}

With the emergence of the concept of sustainable development, reconciling biodiversity conservation and socio-economic development has become a key objective, required by certain measures such as Natura 2000 in Europe. This objective implies a thorough understanding of the status of ecosystems, human activities and their effects on natural resources and biodiversity. Several authors highlight that research in conservation science that lead to concrete management are negligible (Hulme 2011; Braunisch et al. 2012); publications having little impact on the ground (Milner-Gulland et al. 2010; Milner-Gulland et al. 2012) or the results obtained have little operational value (Balmford and Cowling 2006; Knight et al. 2008). According to (Laurance et al. 2012) the measures to remedy these issues would be (1) address issues on the ground, (2) conduct studies that integrate political, social and economic aspects, (3) produce results rapidly enough to meet policy requirements, (4) communicate more directly in the public arena. Conservation measures and practices should be improved by integrating skills with scientific, management, and folk knowledge in a given territory (Irwin 1995). Nassauer and Opdam (2008) propose that studies be, at the same time, a scientific activity and a co-production between researchers and practitioners with the goal of finding solutions. Practitioners skills would be enriched by scientific knowledge and tools while scientists could develop knowledge adapted to a real context (Opdam 2010).

Furthermore, the preservation of natural heritage for future generations implies looking ahead to the evolution of socio-ecological systems. Humans are reflexive, in so far as they modify their behaviours on the basis of knowledge developed through observing natural and social events and through their expectations for the future (Young et al. 2006). We have rapidly 
improved our capacity to develop complex models and simulations of possible futures, and therefore the possibility of choosing a priori one option amongst numerous alternatives that is most adapted (Costanza 2014). Scenario-planning exercises (Peterson et al.2003) were conducted at different spatial levels and for prospective issues (e.g. Costanza 2000; Millennium Ecosystem Assessment 2003; Bohensky et al. 2011), notably for community natural resource management (e.g. Wollenberg et al.2000). These exercises can be complemented with simulations that seek to model future dynamics. Companion modelling (Barreteau et al. 2003, 2014) places local stakeholders at the center of the process by including them in all steps of the process (development of conceptual models, scenarios, indicators) (Etienne et al. 2003; Becu et al. 2008; Gourmelon et al. 2013). This approach incorporates several tools: conceptual model, multi-agent system, geographic information system, simulations based on spatially explicit scenarios, role-playing game. The process and associated tools allow better visualisation of dynamics and interactions and their mobilisation allows stakeholders to exchange points of view, generate hypotheses, propose scenarios and collectively observe the possible consequences of their decision (Bousquet, et al. 2014).

Several studies on natural resource management have been conducted using agent-based modelling (see Dupont et al. 2012) with companion modelling (e.g. Perez et al. 2004; Gurung, et al. 2006; Bousquet et al. 2007; Simon and Etienne 2010; D'Aquino and Papazian 2012; Gourmelon et al. 2013) . But no one, in our knowledge, has concerned biodiversity conservation network Natura 2000 despite its applied interest. Created by the European Union, its objective is to ensure the conservation of endangered heritage species whilst maintaining human activities through a sustainable development perspective, and raising the population's awareness about the respect and management of its designated sites. Natura 2000 is made up of a wide network of protected sites (26 106 sites in 2011) (Evans 2012). The 
European Commission allows Member States to determine the process of designation of sites and the management approaches to be adopted (Electronic Supplement 1). In France, the management of Natura 2000 sites is based on a concertation process, open to all local stakeholders and predicated on the collective preparation of a Natura 2000 Management Plan (Evans 2012). The decline of agriculture and tourism traffic are recurrent issues in consultations and management actions implemented as part of Natura 2000 in France. These two dynamics are associated with landuse changes, which are particularly frequent in coastal areas have been identified as negative factors for biodiversity in coastal regions (Laiolo et al. 2004; Kerbiriou et al. 2008; 2009).

Our hypothesis is that Natura 2000 is ideal for companion modelling based on 1) information about socio-ecosystems gathered in the Management Plan that are necessary for modelling the system, 2) stipulations regarding management actions to meet objectives that constitute a basis for scenarios to be tested, 3) the presence of a network of stakeholders involved in and aware of local issues. To test our hypothesis, our study was conducted at a site affected by these dynamics. Local stakeholders were mobilised to co-construct a model representing the socio-ecosystem in which they have a vested interest, and to develop prospective scenarios to produce simulations of potential developments for biodiversity. In this context, companion modelling should 1) strengthen the common vision of stakeholders regarding the socioecosystem, 2) develop knowledge with the goal of refining management strategies by bringing to light trends in biodiversity indicators in relation to various prospective simulations.

\section{Materials and methods}

\subsection{Study site}

\subsubsection{Location and description of site}


The Natura 2000 site of the Crozon peninsula is located at the western tip of the Britany (4815'39' 'N, 4³0’00'’O) (Fig 1). Its surface area measures 4382 ha, of which 3672 ha are on land, and part of which is a listed site According to the nature heritage, the site have received the status of "Classified Site" which led to total protection against any human construction. The site is made up of a patchwork of vegetation, cliffs, dunes, heathlands, bogs, wet coastal regions, scrub, thickets and agricultural land. Twenty-two habitats of community interest represent (excluding foreshores) 18.85\% (approximately 630 ha) of the land surface. The dry European heathlands represent $79 \%$ of the area's priority habitats. The habitats and species of community interest are listed in Electronic Supplement 2

\subsubsection{Natura 2000 approach, stakeholders and issues}

The main objective stated in the Natura 2000 management plan (Gueguen 2006) for the Crozon peninsula is the conservation of habitats in the state which allows for the most ecological richness and variety. The stipulated actions concern two main threats to biodiversity: significant tourist traffic and agricultural decline. On the one hand, the large concentration of visitors is the main cause of degradation of coastal vegetation through trampling. On the other hand, the sites "maintained" through extensive mowing and grazing practices are overgrown, since these practices have been abandoned, leading to the closing over and uniformisation of areas. The growth of conifers (Pinus pinaster) also contributes to the closing over of coastal areas and threatens heathlands in particular.

The first part of the Management Plan, drawn up in 2006, describes the conservation status of natural habitat and species that warranted the designation of the site, the regulatory protection measures and the human activities carried out on the site. On this basis, the stakeholders who play a role in the development of the habitats were identified: Natura 2000 Project Manager, institutions in charge of managing natural areas (Finistère Territorial and Marine 
Departmental Directorate, Coastal Conservation Authority, Armoric Regional Nature Park, Department of Natural Areas of Crozon Municipality), agriculture actors (Chamber of Agriculture, Farmers), and associations concerned by nature conservation (Crozon Hunting Society, Britany Society for the Study and Protection of Nature).

\subsection{Modelling and simulations}

The methodology, we adopted, was based on three main steps: conceptual modelling and validation of the model, development and validation of the software prototype, scenarios and indicators (Fig 2). Local stakeholders were involved in the conceptual modelling steps, prospective simulation and definition of biodiversity indices (Fig 2)with the aim of facilitating their appropriation of the results (Becu et al. 2008).

\subsubsection{Co-construction of a conceptual model}

The ARDI method (Etienne et al. 2011) is used in companion modelling to co-construct a conceptual model according to a specific participatory protocol. This method, which consists of determining the stakeholders, resources, dynamics, interactions as well as temporal and spatial scales of the model, requires bringing stakeholders together on several occasions. To facilitate the co-construction process, we applied two variants to the companion process: 1) we used, as our basis, a conceptual model (CM) developed during previous projects with similar issues and methodology (Levrel et al. 2009; Rouan et al. 2010; Gourmelon et al. 2013); 2) the stakeholders impacted by the issue were met with individually to discuss and adapt the pre-existing model to the Crozon peninsula Natura 2000 site. The Natura 2000 Project Manager was solicited first to draw up a first draft of the CM, omitting, complementing and declining the agents and resources used in the pre-existing models (Electronic Supplement) and identify the stakeholders. Representatives of the identified 
stakeholders (see Supplementary Material S2) were then met with individually to refine, enrich and question the CM draft. From each of these meetings, which lasted on average two hours, a conceptual model was extracted, which was the most exhaustive possible in relation to the issue of tourist traffic and the closing in of vegetation, including stakeholders, resources (semi-natural habitats and landuses), the dynamics and conditions of change in vegetation in relation to the actions of stakeholders, as well as the rules regulating the actions of stakeholders.

\subsubsection{Validation of conceptual model}

The typology and habitat dynamics, based on vegetation composition, suggested by the stakeholders were evaluated by two botanists who refined some habitat dynamics. The CM (Fig. 3 and Electronic Supplement 4) was then presented during a workshop that brought together the stakeholders in order to be corrected, refined and validated.

The human actions integrated into the model can be grouped into three categories:

- Tourist traffic, which is present year round at different intensities according to the seasons and coastal areas. The impact on habitats was modelled according to a pre-established model used in studies conducted on Ushant (i.e. Kerbiriou et al. 2008).

- The conservation actions determined by the owners (Crozon Municipality, General Council, Coastal Conservation Agency) or by the Natura 2000 Project Manager, are varied. Three main types of actions were selected in relation to the issue being addressed: 1) the protection of certain areas and the laying out of paths: the outcome of this action is that there is no longer trampling of the vegetation in the protected areas; 2) the cutting of conifers and removal of conifers on heathland which prevents pine trees from overgrowing the low-lying heathlands;

3) the maintenance of heathlands and the creation of patchwork areas: medium overgrown heathlands are restored, high heathlands are maintained and gorse thickets are cut down. 
- Agricultural actions (restoration maintenance of meadows) and actions carried out by municipal hunting societies (maintenance of paths and meadows) take place mainly inland and counteract the natural dynamic of the closing over of areas (Fig. 3). These actions are stable in terms of periods of implementation and land surfaces from one year to another.

\subsubsection{Implementation of software prototype}

The software prototype was developed with the multi-agent simulation platform CORMAS (Bousquet et al. 1998), this choice allowed to used scripts already developed for a similar project (Rouan et al. 2010). Resource dynamics and stakeholder actions were coded with the object-oriented language Smalltalk, following the validated CM. The platform allows the implementation of spatial multi-agent models, in which space, considered realistic, is represented by a cellular automaton generated by a Geographic Information System (GIS) (e.g. Rouan et al. 2010). For the Crozon peninsula, the GIS that was carried out is made up of vector data layers which are necessary for creating the model's space (Electronic Supplement 5). A rasterization process produces a multi-variable cell grid comprising the values for each data layer. Vector data having been rasterised at a resolution of $14.14 \mathrm{~m}$, the map obtained is made up of $1,046,430$ cells of $200 \mathrm{~m}^{2}$.

\subsubsection{Validation of software prototype}

The first layer of habitats, produced by the National Botanical Conservatory of Brest (see Electronic Supplement 5) according to a standardised method developed for its use as part of Natura 2000, is from 1999. In order to validate the hypotheses that were modelled in the software prototype, simulations were carried out at time projection of 14 years with the aim of obtaining a map that represents habitats observable on the ground in 2013. Simulated human activities feature: 1) stable frequenting of sites, 2) yearly opening actions and maintenance of 
open areas by hunters, 3) the conservation actions listed during this period, 4) the abandonment or maintenance of agricultural meadow according to the area's history of exploitation.

The quality of the simulated information (vegetation habitats in 2013) was assessed by 1509 geolocalised control points in 2013 (Electronic Supplement 6). The vegetation map obtained by simulation for the year 2013 (Electronic Supplement 6) is valid by $66.4 \%$ in relation to the field observations. Among the 507 items for which a difference was found between the predictions by the CM and field observations in 2013 (Electronic Supplement 6), 111 (22\%) are due to the rasterization process, $163(32 \%)$ are associated with very local constraints that apply to the habitat dynamics and were not taken into account in the conceptual model (see Electronic Supplement 6).

\subsubsection{Scenarios}

In companion modelling, the creation of scenarios and simulations does not aim to predict the future, but to assess the impact of plausible events (Etienne et al. 2011).

The scenarios were developed during a group workshop. The time projection of the simulation was set at 15 years because, according to the participants, a longer time frame would not provide material relevant to the current management. The scientist facilitating the session opened up discussions on potential developments in tourism traffic, agriculture and conservation actions from which several possible scenarios emerged. However, no priority was set collectively. Scientists therefore chose five scenarios resulting from a compromise between their understanding of the value of the scenarios for the stakeholders (function of time spent discussing the scenario and the consensus established about its importance) and feasibility in terms of available data. 
- "Current Trends" (CT). This is a trend scenario based on the most plausible developments according to participants, namely stable tourist traffic numbers, the continuation of agricultural activities on the parcels currently in use, and conservation actions such as those implemented since the formalization of the Natura 2000 site (in 2006).

- "Sustained Management" (SM). This exploratory scenario differs from the previous by a larger number of conservation actions, according to the recommendations of the Natura 2000 Management Plan (Gueguen 2006). Actions (protection of areas, cuts to conifers) were planned in time and space, as a function of the priorities outlined in the Management Plan. Other actions (cutting heathlands and thickets) are carried out at constant rate (60 ha) each year, in randomly selected areas.

- "Stopping Agricultural Activities" (SA). Even though this exploratory scenario is unrealistic in the short term, the question of maintaining agriculture worries stakeholders. The recovery of existing farms is not guaranteed, nor is the renewal of aid such as AEM (Agrienvironmental Measures) ${ }^{1}$. This scenario differs from the trend scenario by the absence of agricultural activities.

- "Without Agriculture and Without Conservation Actions" (WoA). This scenario allows us to differentiate the effects related to agricultural activities and those related to conservation actions on the indicators.

For more information on the actions modelled according to the scenarios, see Electronic Supplement 7.

\subsubsection{Biodiversity indicators}

The impact of different socio-ecological dynamics on biodiversity according to the management scenarios were examined in terms of several indicators of biodiversity status

\footnotetext{
${ }^{1}$ The agri-environmental measures (AEM) are one of the measures to support farming practices that respect the environment, introduced in France in the context of the European policy on supporting rural development.
} 
during a workshop with stakeholders. They were set for their relevance to stakeholders whose objective is to promote the diversity of habitats and species, but also the maintenance of characteristic species and/or strong heritage issues. Three main types of indicators were hence used: i) the surfaces of different habitat types, characterizing the closed over status of the areas, ii) plants and birds community indices (Table 1) and iii) population dynamic of a threatened birds species, the chough (Pyrrhocorax pyrrhocorax).

Community indices characterised the diversity and heritage quality of communities of plants and birds: hereafter the species richness, the community rarity and the community specialisation indices per habitat. Specialist species that have narrower niche width (affinity for a greater number of habitats) are indeed expected to be more sensitive to environmental changes than generalists (Matthews et al. 2014). Under anthropogenic changes, they tend to be proportionally less and less well-represented in communities (Devictor et al. 2008). Calculated at the community level as the average value of the species belonging to the community, these rarity and specialisation indices hence reflect the responses of a large number of species, in interaction, to changes in environmental conditions. They are thus more widely used to assess biodiversity status facing global changes (Devictor et al. 2008; Devictor et al. 2008; Le Roy et al. 2014). For more details on plants and birds community indices see Electronic Supplement 4.

Chough population dynamics was performed using an individual-centred model spatially explicit. The chough is a specialist species using foraging habitats whose main requirement is low vegetation height: grassland and heathlands, dunes and pasture The connection between the population dynamics of choughs and other agents (managers, farmers, and tourists) are based on the impact of these agents upon the dynamics of chough's foraging habitats according to the relationship between quality of the chough territory around the nest 
(Kerbiriou et al. 2006; for more details on the modelling Chough population dynamics see Electronic Supplement 8).

\section{Results}

Due to the low variance in the results obtained from simulations of the same scenario, the simulations were repeated ten times for each of the four scenarios.

\subsection{Development of habitat surfaces}

\subsubsection{Between 1999 and 2013}

The validation of the software prototype allows the comparison of the surfaces occupied by the different types of habitats between 1999 and 2013. Results showed that dynamics of closing over is happening in 13.8 ha of scrub and in 104.6 ha of additional blackthorn thickets in 2013, while meadow surfaces and overgrown meadows decreased (-6 ha and -73.6 respectively) (Table 2). The area of conifer heathlands decreased, while the surface of mature pine forests increased by 56.7 ha.

\subsubsection{According to the scenarios (2013-2028)}

Considering the total area occupied by closed vegetation stages (pine, heathland, pre-forest and gorse thickets, blackthorn thickets), the results of the CT scenario indicate relative stability (-20 ha); 244 ha of additional open areas are found at the end of the SM simulation scenario, while 161 ha and 212 ha close in the SA and WoA scenarios (Table 2).

Surfaces impacted by trampling (short grassland, aerohaline grassland, short heathlands) are not very different regardless of the scenario, probably because it occurs only in limited areas and in habitats sparsely represented on the site.

\subsection{Evolution of biodiversity indicators according to scenarios}


To compare the results for the same indicators between different scenarios, the values calculated by habitat (Table 2) were weighted by their respective surfaces (variable evolving through simulations and according to scenarios) and then summed to obtain a total value for all habitats.

\subsubsection{Plant communities}

Species richness can be considered stable for the CT and SM scenarios (Fig. 4a). In the scenarios without agriculture (SA and WoA), richness increases due to the shrub expansion in meadows. Uncultivated meadows have indeed a higher species richness than meadows not overgrown with shrub (Table 2). Species richness decreases at the rate of vegetation succession which leads to the blackthorn, vegetation formation with fewer species (Table 2), stabilizing at a value less than that of 2013 (beginning of the simulation).

The likelihood of encountering rare species is higher in the SM scenario (Fig. 4b) due to restoration actions and maintenance of the heathlands that host rare species as well as thickets (Table 2). The likelihood of encountering rare species is stable in the CT scenario. The cessation of agricultural activities (SA and WoA) would have negative consequences for rare species because of the encroachment of grasslands and their evolution to blackthorn thickets.

\subsubsection{Bird communities}

When there is no longer agricultural activity (SA and WoA), specialised agricultural area species are less abundant, which results in a site-wide decrease in the average level of specialisation of communities (Fig. 4d). Habitats where the most specialised species are found are coastal, aerohaline and short grassland, as well as meadows. Thus, with the dynamics of bush overgrowth, meadow species are replaced by the less specialised blackthorn thicket species (Table 2). 
However, there are fewer rare species in the groups of meadow species than in blackthorn thickets (Table 2); the index of rarity increases in cases where there is no more agriculture (SA et WoA) (Fig. 4c). The index decreases and is lower for the SM scenario compared to the CT scenario, due to fewer areas with blackthorn thickets and pines.

\subsubsection{Chough population dynamics}

The best scenario for chough population dynamics are CT and SM whereas the two scenario without agricultural activity (SA and WoA) seem less favourable for chough population (Fig. 5)

\section{Discussion}

\subsection{Responses from biodiversity indicators to scenarios}

As in many Natura 2000 sites, the Crozon peninsula is facing to an active process of closing over. The (1999-2013) simulation conducted to validate the model indicates the expansion of pine forest and of thickets brought on by the decline in agriculture. The most plausible evolution (CT scenario) shows that the maintenance of actions initiated since the implementation of Natura 2000 would maintain species richness and the presence of rare species within plant communities, the presence of specialist species within bird communities, encourage the presence of rare species of birds and are the more favourable the focus species (chough). The simulation results of other scenarios indicate that the different biodiversity indicators can respond in opposite ways within the same scenario. Multiplying conservation actions (SM scenario) which are characterised by a reduction of closed surface areas (pine and blackthorn thickets) and an increase in open areas (meadows, short heathlands and aerohaline grassland), has the opposite effect on rare species in different communities. The impact is therefore positive for the average degree of rarity of plant communities (the short heathlands 
and grasses are habitat for rare plants such as Dactylis glomerata oceanica, Ulex europaeus maritimus, Anagallis arvensis parviflora) and negative for the average degree of rarity of bird communities (meadows have fairly common birds such as Alauda arvensis, Turdus merula, Columba palumbus). The stoppage of agricultural activities (SA and WoA scenarios) would have negative effects on plant communities (decrease in species richness and the presence of rare species), the specialist bird species, namely in open areas maintained by agricultural practices (Pyrrhocorax pyrrhocorax, Emberiza calandra, Alauda arvensis, Anthus pratensis), while it would favour certain species of rare birds in the area examined, for which the biotope is one of the more closed over areas (Caprimulgus europaeus, Locustella naevia,Cettia cetti).

\subsection{Appeal of a local approach}

These results highlight two points regarding applied research in biodiversity conservation. First, research conducted at the site level can help in avoiding pitfalls due to generalisation. For example, agricultural activities are often seen as a biodiversity loss factors on the global scale (Green et al. 2005; Stoate et al. 2009; Balmford et al.2012) justifying the challenge of limiting the conversion of natural habitats to agricultural land (McLaughlin 2011). Yet, the extensive and diversified agriculture carried out on the study site plays an important role in maintaining rare and specialist species. Extensive agriculture can help protect biodiversity, particularly in areas in Europe where there is a long agricultural history (Rosenzweig 2003), some agricultural area types clearly containing more biodiversity and ecosystem services than others (Daily 2001).

Second, none of the scenarios favour all biodiversity indicators, reflecting the difficulty in meeting an overall objective of "optimising biodiversity" and raises the question of which species/biotopes should be prioritised. Some scientific studies suggest conservation prioritysetting approaches (Brooks et al. 2006) by integrating environmental, social and economic 
criteria (Balmford et al. 2000; Possingham et al. 2001; Wilson et al. 2006; Bottrill et al. 2008;

Freudenberger et al. 2013). Performed at global and national levels, these initiatives are intended to identify priority conservation areas and/or facilitate financing. In order to make the conservation of biodiversity effective, the companion modelling approach is complementary to previous approaches since it is used to locally identify practices required for biodiversity conservation. Furthermore, biodiversity is to be considered across several indicators. Thus, knowledge about the modelled socio-ecological system and the simulation results are used to specify what actions are neutral, promote or oppose which compartments of biodiversity. For example, in the SM scenario, the positive impact for the rare plant species comes from the maintenance of heathlands and the mulching of gorse thickets, while the negative impact on rare bird species comes from removal and the cutting of blackthorn thickets. Highlighting the links between human activities and biodiversity indicators, modelling and simulation on a Natura 2000 site contributes to the selection of conservation actions to be implemented locally as a function of the species to be preserved.

\subsection{Natura 2000 and companion modelling}

Multi-agent models are realistic methodologies which require the availability of various data and knowledge. When implemented with a companion approach, the process of coconstruction presents challenges in bringing together stakeholders with different timetables and objectives, to harmonise points of views and maintain a democratic process (Becu et al. 2008; Gourmelon et al. 2013; Levrel et al. 2009). In our study, the use of a pre-existing model (Rouan et al. 2010; Gourmelon et al. 2013), developed in an area with similar characteristics and challenges, allowed us to save time during the collective work. Namely, the mobilisation of data and stakeholders was facilitated by the Natura 2000 context, which leads stakeholders from the community of interest to work together with a diagnosis based on knowledge and 
data. So, while validating spatial simulations is generally a thorny issue, the existence of a previous map, prepared as part of Natura 2000, allowed validation of the model.

As with several studies mobilising companion modelling (Le Page et al. 2014; Jones et al. 2009; Gourmelon et al. 2013), stakeholders involved in the process, surveyed at the end of the project, believe that the discussion space created during group workshops (1) provides access to a collective vision and/or discussion centred on the future of the study area or on the natural areas, (2) is desirable to foster relationships between local actors operating at different levels and to foster relationships between researchers and local stakeholders. In particular, scenario development and production of results through simulations were considered a useful tool for discussion, bringing relevant elements to the management of natural areas on the Crozon peninsula and promoting collaborative management.

\section{Acknowledgements}

This study was performed under benefit and agreement between the Fondation de France, the MNHN and CNRS. We thank all those who contributed and especially stakeholders involved in modeling; Ségolène Gueguen, Jérémie Bourdoulous, Didier Cadiou, Yannig Coulomb, Isabelle Gay, Michel David, Denis Flotté, Morgan Huteau, Claire Léostic, Lise Vauvert, Joel Le Gall, scientific experts and botanists: Marion Hardegen (National Botanical Conservatory of Brest), Bernard Clement (University Rennes 1), Laurence David (UMR 6554 LETG) and two anonymous reviewers for their helpful comments on the manuscript.

\section{References}

Balmford, A. \& Richard M.C. (2006) Fusion or Failure? The Future of Conservation Biology. Conservation Biology, 20, 692-95. 
Balmford, A., Gaston, K.J., Rodrigues A.S.L. \& James, A. (2000) Integrating Costs of Conservation into International Priority Setting. Conservation Biology, 14, 597-605.

Balmford, A., Green, R. \& Phalan, B. (2012) What Conservationists Need to Know About Farming. Proceedings of the Royal Society B: Biological Sciences 279, 2714-24.

Barreteau, O., Antona, M., D’Aquino P., Aubert, S., Boissau, S., Bousquet, F., Dare, W. et al. (2003) Our Companion Modelling Approach. Journal of Artificial Societies and Social Simulation 6.

Barreteau, O., Bousquet, F., Étienne, M., Souchère, V. \& D’ Aquino, P. (2014) Companion Modelling: A Method of Adaptive and Participatory Research. Companion Modelling (ed M. Étienne), pp. 13-40. Springer Netherlands.

Becu, N., Neef, A., Schreinemachers, P. \& Sangkapitux, C. (2008) Participatory Computer Simulation to Support Collective Decision-making: Potential and Limits of Stakeholder Involvement. Land Use Policy 25, 498-509.

Bohensky, E., Butler, J.R.A., Costanza, R., Bohnet, I., Delisle, A., Fabricius, K., Gooch, M., Kubiszewski, I., Lukacs, G. \& Pert, P. (2011) Future Makers or Future Takers? A Scenario Analysis of Climate Change and the Great Barrier Reef. Global Environmental Change 21, 876-93.

Bottrill, M.C., Joseph, L.N., Carwardine, J., Bode, M., Cook, C., Game, E.T., Grantham, H., Kark, S., Linke, S., \& McDonald-Madden, E. (2008) Is Conservation Triage Just Smart Decision Making? Trends in Ecology \& Evolution 23, 649-54. 
Bousquet, F., Castella, J.C., Trébuil, G., Barnaud, C., Boissau, S., \& Kam, S.P. (2007) Using Multi-agent Systems in a Companion Modelling Approach for Agroecosystem Management in South-east Asia. Outlook on Agriculture 36, 57-62.

Bousquet, F., Bakam, I., Proton, H. \& Le Page, C. (1998) Cormas: common-pool resources and multi-agent systems. Lecture Notes in Artificial Intelligence, 1416, 826-837.

Bousquet, F., Étienne, M. \& D’ Aquino, P. (2014) Introduction. Companion Modelling (ed M. Étienne), pp. 1-12. Springer Netherlands.

Braunisch, V., Home, R., Pellet, J., \& Arlettaz, R. (2012) Conservation Science Relevant to Action: A Research Agenda Identified and Prioritized by Practitioners. Biological Conservation 153, 201-10.

Brooks, T.M., Mittermeier, R. A., da Fonseca, G.A.B., Gerlach, J., Hoffmann, M., Lamoreux, J.F., Mittermeier, C.G., Pilgrim, J.D. \& Rodrigues, A.S.L. (2006) Global Biodiversity Conservation Priorities. Science 313, 58-61.

Costanza, R. (2014) A Theory of Socio-ecological System Change. Journal of Bioeconomics 16, 39-44.

Costanza, R. (2000) Visions of Alternative (unpredictable) Futures and Their Use in Policy Analysis. Conservation Ecology 4, 1- 5. 
Daily, G.C. (2001) Ecological Forecasts. Nature 411, 245-245.

D'Aquino, P., \& Papazian, H. (2012) A Ten-years-after Impact Analysis of a Companion Modelling Approach. Final Evaluation Report. http://hal.archives-ouvertes.fr/hal-00875354/

Devictor, V., Julliard, R., Clavel, J., Jiguet, F., Lee, A., \& Couvet, D. (2008) Functional Biotic Homogenization of Bird Communities in Disturbed Landscapes. Global Ecology and Biogeography 17, 252-61.

Devictor, V., Julliard, R. \& Jiguet, F. (2008) Distribution of Specialist and Generalist Species Along Spatial Gradients of Habitat Disturbance and Fragmentation. Oikos 117, 507-14.

Dupont, H., Mihouub, J.B., Bobbé, S. \& Sarrazin, F. (2012) Modelling carcass disposal practices: implications for the management of an ecological service provided by vultures. Journal Applied Ecology 49, 404-411.

Etienne, M., Du Toit, D.R. \& Pollard, S. (2011) ARDI: a Co-construction Method for Participatory Modeling in Natural Resources Management. Ecology and Society 16.)

Etienne, M., Le Page, C. \& Cohen, M. (2003) A Step-by-step Approach to Building Land Management Scenarios Based on Multiple Viewpoints on Multi-agent System Simulations. Journal of Artificial Societies and Social Simulation 6. 
Evans, D. (2012) Building the European Union's Natura 2000 Network. Nature Conservation $1,11-26$.

Freudenberger, L., Hobson, P., Schluck, M., Kreft, S., Vohland, K., Sommer, H., Reichle, S., Nowicki, C., Barthlott, W. \& Ibisch, P.L. (2013) Nature Conservation: Priority-setting Needs a Global Change. Biodiversity and Conservation 22, 1255-81.

Gourmelon, F., Chlous-Ducharme, F., Kerbiriou, C., Rouan, M., \& Bioret, F. (2013) Roleplaying Game Developed from a Modelling Process: A Relevant Participatory Tool for Sustainable Development? A Co-construction Experiment in an Insular Biosphere Reserve. Land Use Policy 32, 96-107.

Green, R.E., Cornell, S.J., Scharlemann, J.P.W. \& Balmford, A. (2005) Farming and the Fate of Wild Nature. Science 307, 550-55.

Gueguen S. 2006. Document d'Objectifs, Site NATURA 2000 n FR5300019, " Presqu'île de Crozon", 2ème partie : les objectifs et mesures de gestion. [http://presquile-decrozon.n2000.fr/participer/le-docob-du-site-presqu-ile-de-crozon]

Gurung, T.R., Bousquet, F. \& Trébuil, G. (2006) Companion Modeling, Conflict Resolution, and Institution Building: Sharing Irrigation Water in the Lingmuteychu Watershed, Bhutan. Ecology \& Society 11. 
Hulme, P.E. (2011) Practitioner's Perspectives: Introducing a Different Voice in Applied Ecology. Journal of Applied Ecology 48, 1-2.

Irwin, A. (1995) Citizen Science: A Study of People, Expertise, and Sustainable Development. Routledge, London.

Kerbiriou, C., Gourmelon, F., Jiguet F., Le Viol I., Bioret F., \& Julliard R., 2006. Linking territory quality and reproductive success in the chough (Pyrrhocorax pyrrochorax) : implications for conservation management of an endangered population. Ibis 148, 352-364

Kerbiriou, C., Le Viol, I., Jiguet, F. \& Julliard, R. (2008) The impact of human frequentation on coastal vegetation in a biosphere reserve. Journal of Environmental Management 88, 715728

Kerbiriou, C., Leviol, I., Robert, A., Porcher, E., Gourmelon, F. \& Julliard R. (2009). Tourism in protected areas can threaten wild populations : from individual response to population viability of the chough Pyrrhocorax pyrrhocorax. Journal Applied Ecology 46, 657-665

Knight, A.T., Cowling, R.M., Rouget, M., Balmford, A., Lombard, A.T. \& Campbell, B.M. (2008) Knowing but Not Doing: Selecting Priority Conservation Areas and the Researchimplementation Gap. Conservation Biology: The Journal of the Society for Conservation Biology 22, 610-17. 
Laiolo, P., Rolando, A., Valsania, V. (2004) Responses of birds to the natural reestablishment of wilderness in montane beechwoods of North-western Italy. Acta Oecologica 25, 129-136.

Laurance, W.F., Koster, H., Grooten, M., Anderson, A.B., Zuidema, P.A., Zwick, S., Zagt, R.J., Lynam, A.J., Linkie, M. \& Anten, N.P.R. (2012) Making Conservation Research More Relevant for Conservation Practitioners. Biological Conservation 153, 164-68.

Le Page, C., Abrami, G., Barreteau, O., Becu, N., Bommel, P., Botta, A., Dray, A., Monteil, C. \& Souchère, V. (2014) Models for Sharing Representations. Companion Modelling (ed M. Étienne), pp. 69-101. Springer Netherlands.

Levrel, H., Etienne, M., Kerbiriou, C., Le Page, C. \& Rouan, M. (2009) Co-modeling Process, Negotiations, and Power Relationships: Some Outputs from a MAB Project on the Island of Ouessant. Society and Natural Resources 22, 172-88.

Le Roy B., Le Viol I., Petillon J. (2014) Complementarity of rarity, specialisation and functional diversity metrics to assess community responses to environmental changes, using an example of spider communities in salt marshes. Ecological Indicators 46, 351-357.

Matthews, T.J., Cottee-Jones, H.E. \& Whittaker, R.J. (2014) Habitat fragmentation and the species-area relationship: a focus on total species richness obscures the impact of habitat loss on habitat specialists. Diversity and Distributions, 20, 1136-1146.

McLaughlin, D.W. (2011) Land, Food, and Biodiversity. Conservation Biology 25, 1117-20. 
Millenium Ecosystem Assessment (2003) Eco Systems and Human Well-Being: A Framework for Assessment. Island Press, Washington DC.

Milner-Gulland, E. J., Barlow, J., Cadotte, M.W., Hulme, P.E., Kerby, G. \& Whittingham, M.J. (2012) Ensuring Applied Ecology Has Impact. Journal of Applied Ecology 49, 1-5.

Milner-Gulland, E.J., Fisher, M., Browne, S., Redford, K.H., Spencer, M. \& Sutherland, W.J. (2010) Do We Need to Develop a More Relevant Conservation Literature? Oryx, 44, 1-2.

Nassauer, J.I. \& Opdam, P. (2008) Design in Science: Extending the Landscape Ecology Paradigm. Landscape Ecology 23, 633-44.

Opdam, P. (2010) Learning Science from Practice. Landscape Ecology 25, 821-23.

Perez, P., Dray, A., Le Page, C., D’Aquino, P., White, I. \& Auatabu, T. (2004) Lagoon, Agents and Kava: A Companion Modelling Experience in the Pacific. Recent Developments and Applications in Social Research Methodology (6th), Amsterdam. https://crawford.anu.edu.au/rmap/pdf/_docs/Lagoon.pdf.

Peterson, G.D., Cumming, G.S. \& Carpenter, S.R. (2003) Scenario Planning: a Tool for Conservation in an Uncertain World. Conservation Biology 17, 358-66.

Possingham, H. P., Andelman, S.J., Noon, B.R., Trombulak, S. \& Pulliam, H.R. (2001) Making Smart Conservation Decisions. Conservation Biology: Research Priorities for the Next Decade 225-44. 
Rosenzweig, M.L. (2003) Win-win Ecology: How the Earth's Species Can Survive in the Midst of Human Enterprise. Oxford University Press.

Rouan, M., Kerbiriou, C., Levrel, H. \& Etienne, M. (2010) A Co-modelling Process of Social and Natural Dynamics on the Isle of Ouessant: Sheep, Turf and Bikes. Environmental Modelling \& Software 25, 1399-1412.

Simon, C. \& Etienne, M. (2010) A Companion Modelling Approach Applied to Forest Management Planning. Environmental Modelling \& Software 25, 1371-84.

Stoate, C., Báldi, A., Beja, P., Boatman, N.D., Herzon, I., Van Doorn, A., De Snoo, G.R., Rakosy, L. \& Ramwell, C. (2009) Ecological Impacts of Early 21st Century Agricultural Change in Europe-a Review. Journal of Environmental Management 91, 22-46.

Wilson, K.A., McBride, M.F., Bode, M. \& Possingham, H.P. (2006) Prioritizing Global Conservation Efforts. Nature 440, 337-40.

Wollenberg, E., Edmunds, D. \& Buck, L. (2000) Using Scenarios to Make Decisions About the Future: Anticipatory Learning for the Adaptive Co-management of Community Forests. Landscape and Urban Planning 47, 65-77.

Young, O.R., Berkhout, F., Gallopin, G.C., Janssen, M.A., Ostrom, E. \& van der Leeuw, S. (2006) The Globalization of Socio-ecological Systems: An Agenda for Scientific Research. Global Environmental Change 16, 304-16. 
Figure 1. Map of the Crozon peninsula and the Natura 2000 site

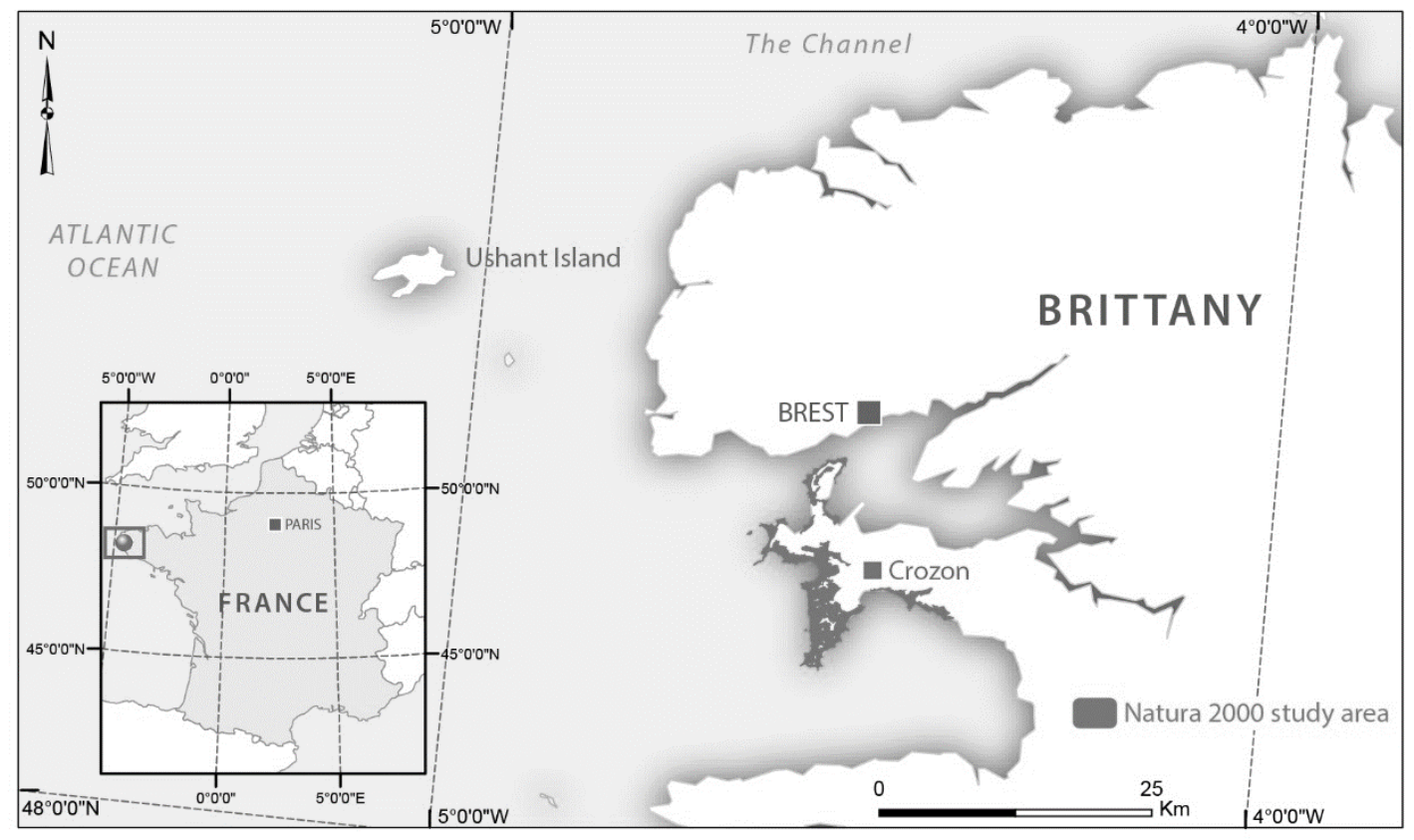

Figure 2. Progress of the project and involvement of stakeholders in the process

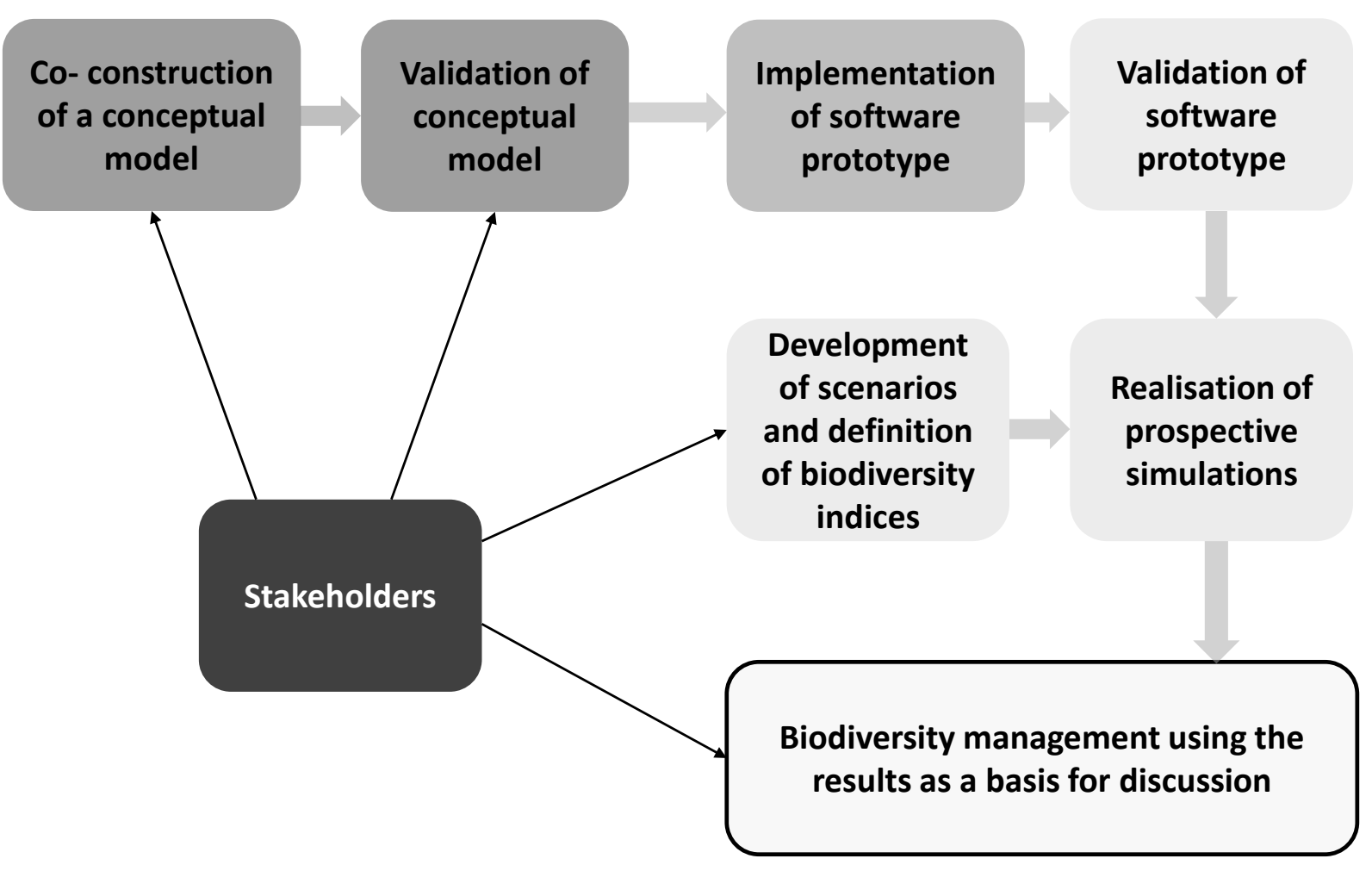


Figure 3. Vegetation dynamics and human actions modeled. Habitats are represented in a gradient of habitat openness (bottom to top) and the distance to the coast (from right to left).

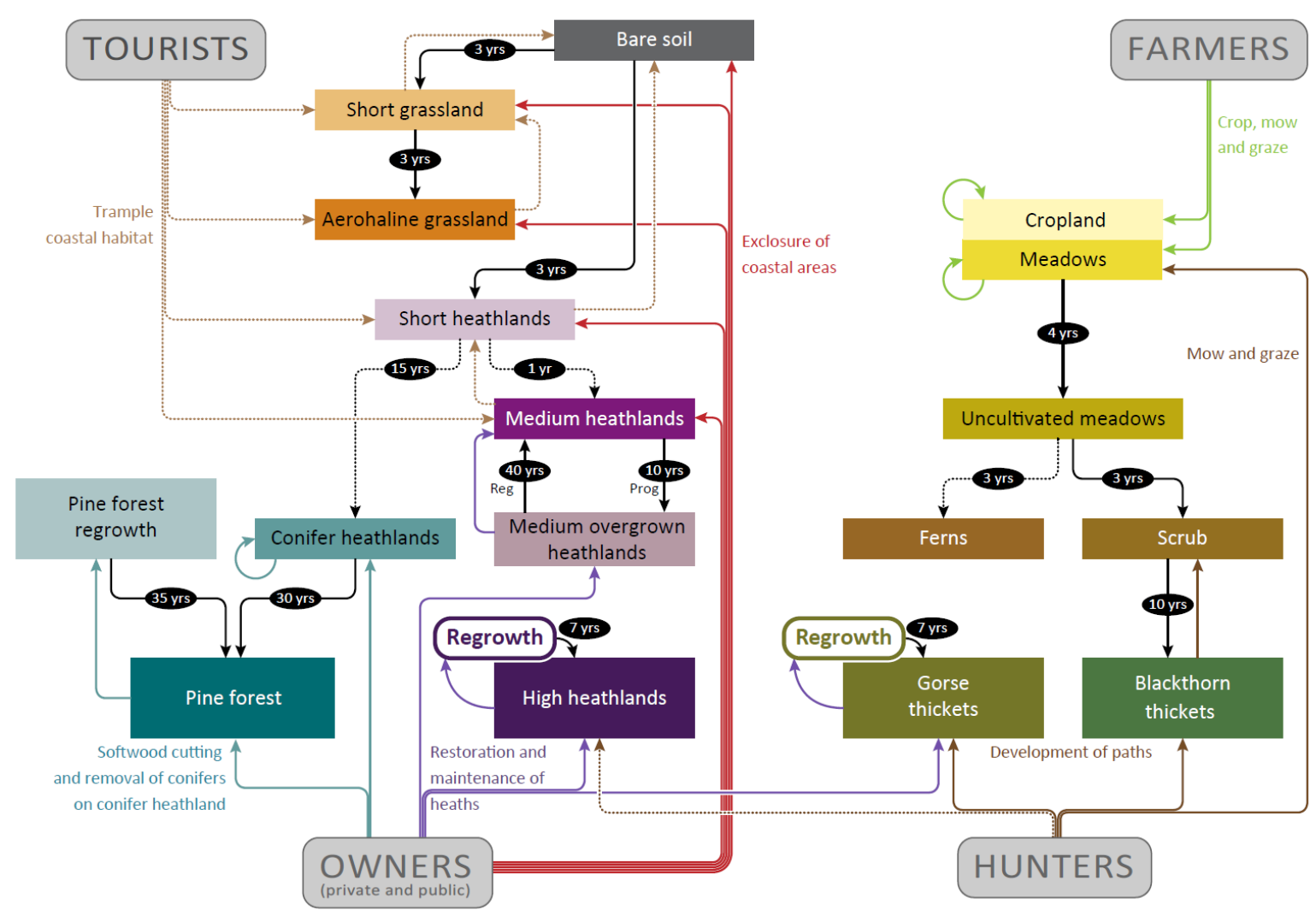


Figure 4. Evolution of biodiversity indicators of community based on performed scenario (CT: Current Trends; SM: Sustained Management; SA: Stopping Agricultural Activities; WoA: Without Agriculture and Without Conservation Actions). The scale of the graphics has been transformed so that the initial situation (2013) corresponds to the value 1 .
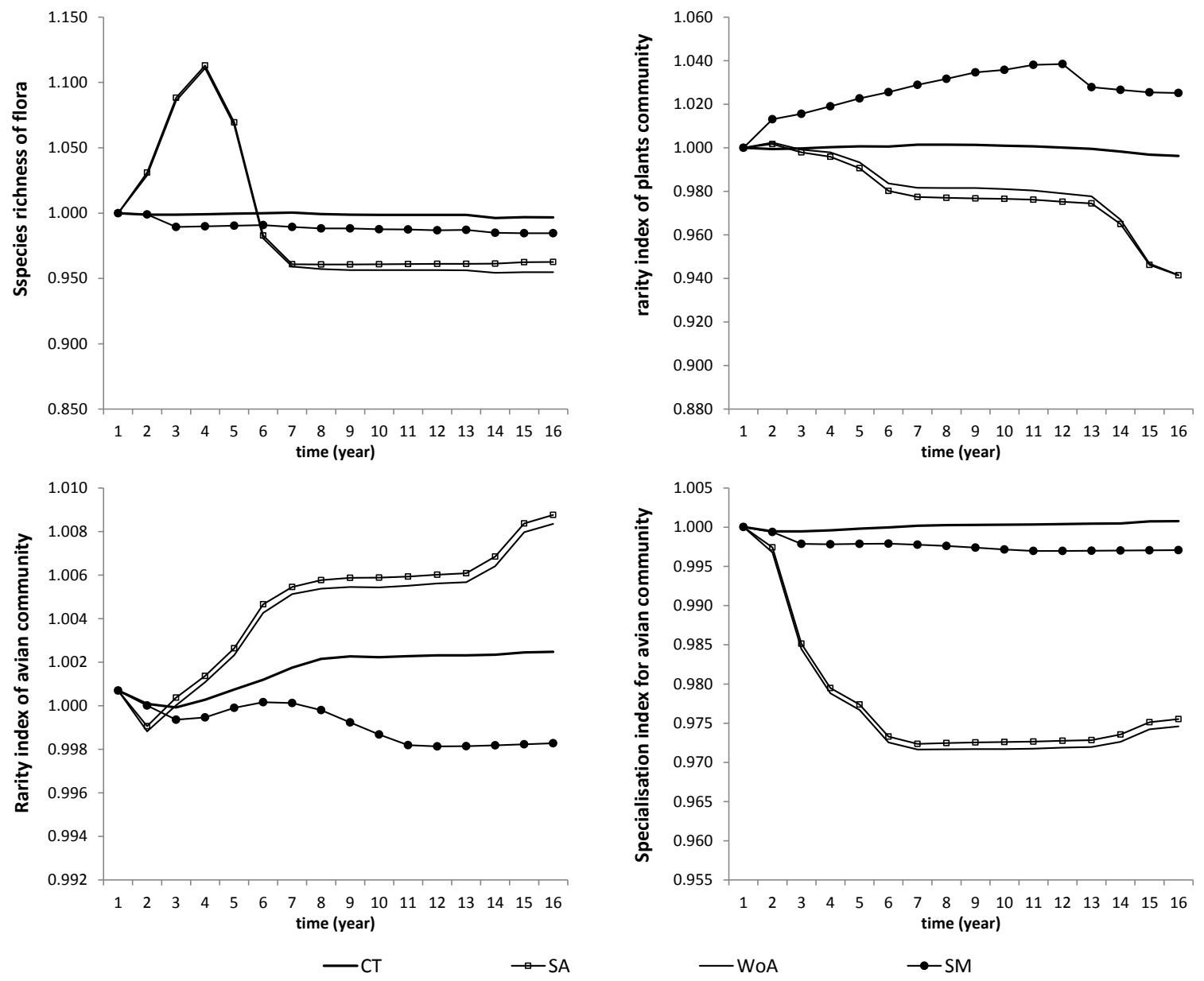
Figure 5. Evolution of chough population index based on performed scenario (CT: Current Trends; SM: Sustained Management; SA: Stopping Agricultural Activities; WoA: Without Agriculture and Without Conservation Actions). The scale of the graphics has been transformed so that the initial situation (2013) corresponds to the value 1 and the SM, SA and WoA scenario are scaled to CT scenario.

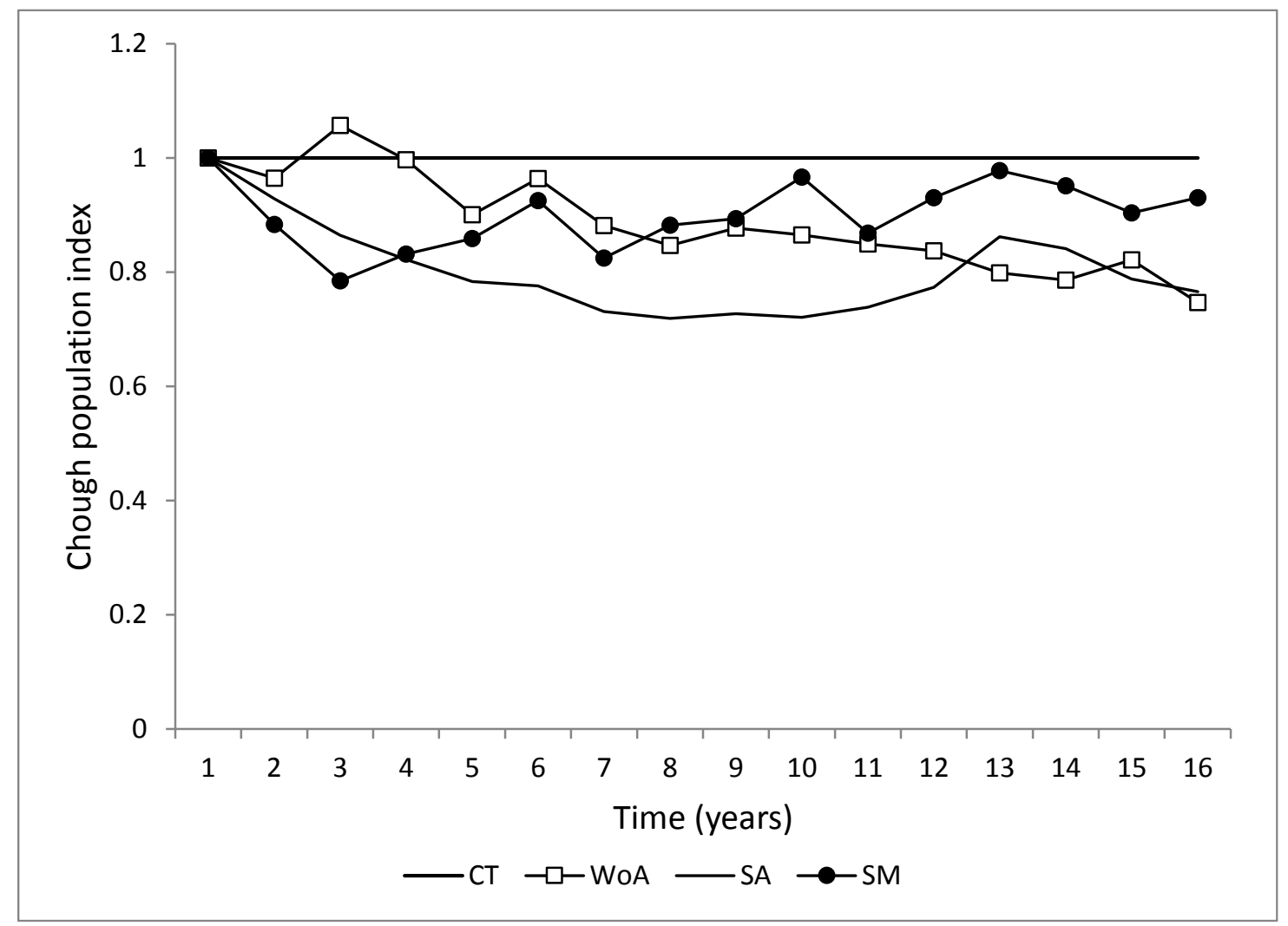

